\title{
PERBANDINGAN MORTAR BERPASIR PANTAI DAN SUNGAI
}

\section{Yusuf Wahyudi}

Jurusan Sipil FT Universitas Muhammadiyah Malang yusufunmuh@yahoo.com

\section{ABSTRACT}

The use of sand beach as building material is very rarely used because considering the possible damage toward the other building materials that caused by salt content in it. This research is aimed to provide an overview comparison of mortar with sand beach and Brantas River, and also the use of cement type Ordinary Portland Cement (PC) and Portland Pozzoland Cement (PPC).

The result of this research showed that the average weight of sand beach is $1.7739 \mathrm{ton} / \mathrm{m}^{3}$ the average of dry density: 2.55 , the avarege of SSD density: 2.63 , the average of appearance density: 2.83 , the average of absorption: $2.16 \%$. The value of sand silt in Sendang Biru beach is $1.452 \%$, while for Brantas River is $1.424 \%$. The best compressive strength of mortar was showed by the mixing of $20 \%$ of pp Sendang Biru and $80 \%$ of ps Brantas River, that is $318,479 \mathrm{~kg} / \mathrm{cm}^{2}$, or about $28.5 \%$ bigger than mortar control (1pc cement: 3ps Brantas) that is $247,706 \mathrm{~kg} / \mathrm{cm}^{2}$. Furthermore, the compressive strength of pc mortar cement substituted by sand beach is decrease to $68 \%, 25 \%$, and $22 \%$, while for the mixing of pp Sendang Biru compared with ps Brantas $60 \%: 40 \%, 80 \%: 20 \%$, and 100\%:0\%. The average compressive strength of pc cement mortar is higher than the average compressive strength of ppc cement mortar in 28 days. The compressive strength of mortar $1 \mathrm{pc}: 3$ sand in the mix of $100 \%$ ps Brantas pc cement is $373.2 \mathrm{~kg} / \mathrm{cm}^{2}$. Furthermore, the compressive strength of mortar subtitued with sand beach $20 \%, 40 \%, 60 \%, 80 \%$, and $100 \%$ each is decreased to be $97.4 \%, 74.5 \%, 58.2 \%, 31.5 \%$, and $22.8 \%$ from value control.

Keyword: characteristic, compressive strength, mortar, sand beach, Portland cement, pozzolan cement.

\section{PENDAHULUAN}

Karya tulis ini adalah bentuk publikasi dari kajian tentang penggunaan pasir pantai pada campuran mortar, dengan pembanding mortar berbahan pasir sungai Brantas, serta pemakaian jenis semen Ordinary Portland Cement (PC) dan Portland Pozzoland Cement (PPC). Selanjutnya artikel yang terpublikasikan

Melalui seminar nasional, bertujuan untuk memberikan informasi kepada masyarakat pengguna mortar tentang pemakaian pasir pantai dalam mortar dengan perekat semen PC dan PPC. Penulisan karya ini belum disertai uraian kerugian dan keuntungan yang diakibatkan pemakaian pasir pantai secara lengkap, tetapi sebagai langkah awal untuk memanfaatkan sumber daya pantai serta mengurangi penggalian pasir sungai. Pemanfaatan material yang terdapat di permukaan, melalui bidang teknik sipil sangat diharapkan untuk kesejahteraan masyarakat

70 |Media Teknik Sipil, Volume 10, Nomor 1, Februari 2012: 70 - 79 2006)

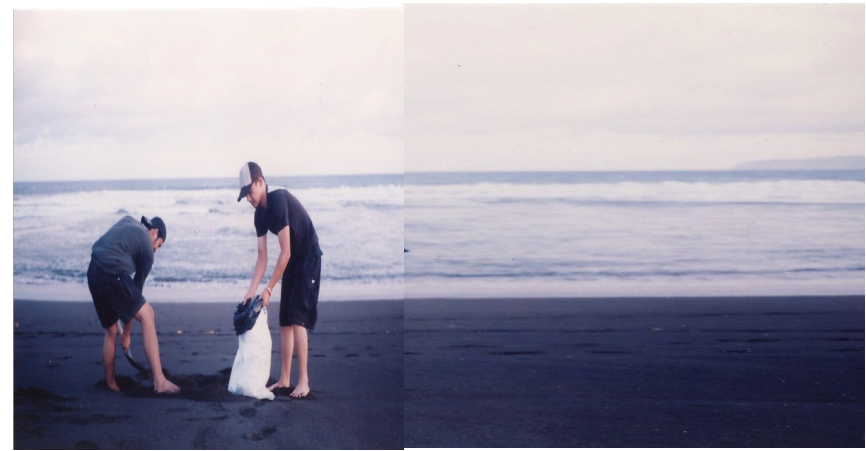

Gambar 1. Hamparan pasir pantai selatan di pantai Sendangbiru

Penambangan pasir di dasar sungai dilakukan untuk memenuhi permintaan masyarakat. Berbagai lokasi penambangan di sungai Konto di Kediri, atau di sungai Pasirian Lumajang, sungai Brantas Mojokerto, sungai Bengawan Solo di Bojonegoro, sungai Brosot di Bantul; Kemudian penambangan di gunung, seperti: Merapi di Magelang, gunung Semeru di Lumajang. Penambangan dari lahan terbuka, misalnya: Gununggangsir Pasuruan, Blabak Magelang. Aktifita penambangan yang dilakukan terus menerus, tanpa memperhatikan aturan atau pertimbangan yang bijaksana, maka menimbulkan dampak yang merugikan. Kerugian dapat berakibat langsung, atau di masa depan, misalnya keseimbangan alam terganggu, longsor, dan berkurangnya kestabilan bangunan sipil di sepanjang aliran sungai.

Manusia dan lingkungannya berada dalam keadaan seimbang, maka keduanya berada dalam keadaan sehat. Tetapi karena sesuatu sebab sehingga keseimbangan tergangggu atau mungkin tidak dapat tercapai, maka dapat menimbulkan dampak yang merugikan bagi kesehatan, atau sisi lainnya (Eddie, W.S., 2006). Pengolahan sumber daya alam yang memperhatikan keseimbangan lingkungan sangat dibutuhkan untuk meningkatkan kesejahteraan masyarakat. Salah satu alternatif untuk mengurangi dampak ketidakseimbangan alam yaitu menemukan bahan baru yang berfungsi sama dengan pasir, atau mencari lahan pasir baru misalnya di daerah pesisi atau pantai.

Alik Ansyori Alamsyah, Penggunaan Pertamax Sebagai Modifier Pada Lasbutag Campuran Dingin $\mid 71$ Untuk Perkerasan Jalan
Mortar

Mortar atau spesi, atau adukan, menurut Murdock, R. (1980) adalah campuran yang tersusun atas semen, pasir, air, dalam waktu tertentu akan mengeras seperti batuan. Mortar berfungsi perekat diantara bata merah dalam pembuatan dinding di dalam rumah atau di luar rumah, perekat batu kali pada konstruksi fondasi, atau sebagai lapisan plasteran pada permukaan dinding bata, atau yang lain. Bahan mortar dapat juga ditambahkan bahan tambah untuk mempercepat pengerasan atau tujuan yang lain (Tjokrodimuljo,1996).Ciri spesi yang baik yaitu murah, kuat atau tahan lama, mudah dikerjakan (diaduk, diangkat, dipasang, dan diratakan), merekat dengan baik dengan bata, batu, dan sebagainya, cepat kering atau keras, tahan terhadap rembesan air, dan tidak timbul retak-retak setelah dipasang (Trimulyono, 2004). Semen

Bahan dasar semen ialah batu kapur dan tanah liat dari alam yang memiliki berbagai oksida. Semen adalah dihasilkan dengan cara menghaluskan klinker yang terutama terdiri dari silikat kalsium yang bersifat hidraulis dengan gips sebagai bahan tambahan (PUBI1982). Pasta semen berfungsi sebagai perekat agregat dan mengisi ruang antar agregat agar menjadi massa yang kompak atau padat. Pacitan, Kecamatan Parangtritis Kabupaten Bantul, dan beberapa daerah pesisir lainnya (Wahyudi, Y., 
Tabel 1. Perkiraan komposisi oksida semen portland

\begin{tabular}{cc}
\multicolumn{3}{c}{ portland } \\
\hline Oksidasi & J umlah (\%) \\
\hline $\mathrm{CaO}$ & $60-67$ \\
$\mathrm{SiO}_{2}$ & $17-25$ \\
$\mathrm{Al}_{2} \mathrm{O}_{3}$ & $3-8$ \\
$\mathrm{Fe}_{2} \mathrm{O}_{3}$ & $0,5-6.0$ \\
$\mathrm{MgO}^{2}$ & $0,1-4.0$ \\
$\mathrm{Alkali}\left(\mathrm{K}_{2} \mathrm{O}+\right.$ & $0,2-1,3$ \\
$\mathrm{Na2O}$ & \\
$\mathrm{SO}_{3}$ & $1-3$ \\
\hline
\end{tabular}

Sumber : Neville, 1981

Semen terdiri dari 4 senyawa pokok, yaitu : (a) trikalsium silikat (3 $\mathrm{CaO} . \mathrm{SiO} 2)$ atau $\mathrm{C} 3 \mathrm{~S}$, (b) dikalsium silikat (2 $\mathrm{CaO} . \mathrm{SiO} 2)$ atau $\mathrm{C} 2 \mathrm{~S}$, (c) trikalsium aluminat (3 $\mathrm{CaO} . \mathrm{Al} 2 \mathrm{O} 3$ ) atau $\mathrm{C} 3 \mathrm{~A}$, (d) tetrakalsium aluminoferit (4 CaO.Al2O3. $\mathrm{Fe} 2 \mathrm{O} 3$ ) atau $\mathrm{C} 4 \mathrm{AF}$ Kalsium silikat bereaksi dengan air menghasilkan kalsium silikat hidrat (calsium silicate hydrate atau CS-H) dan kalsium hidroksida. Reaksi unsur semen dan air membentuk kalsium silikat hidrat yang keras.

$$
\begin{aligned}
& 2\left(3 \mathrm{CaO} \cdot \mathrm{SiO}_{2}\right)+6 \mathrm{H}_{2} \mathrm{O} \circledast 3 \mathrm{CaO} \cdot \mathrm{SiO}_{2} \cdot 3 \mathrm{H}_{2} \mathrm{O} \\
& \quad+3 \mathrm{Ca}(\mathrm{OH})_{2} \\
& 2\left(2 \mathrm{CaO} \cdot \mathrm{SiO}_{2}\right)+4 \mathrm{H}_{2} \mathrm{O} \circledast 3 \mathrm{CaO} \cdot 2 \mathrm{SiO}_{2} \cdot 2 \mathrm{H}_{2} \mathrm{O} \\
& \quad+\mathrm{Ca}(\mathrm{OH})_{2}
\end{aligned}
$$

C-S-H padat berongga yang belum sempurna disebut tobermorite. Jumlah tobermorite gel 70\% dari semen. $\mathrm{Ca}(\mathrm{OH}) 2$ bersifat basa kuat $(\mathrm{pH}=12,5)$, sehingga mencegah korosi baja tulangan dalam beton. Reaksi $\mathrm{C}_{3} \mathrm{~A}$ dengan air, diikuti dengan kenaikan kuat tekan pasta (flash set), hidrasi $\mathrm{C}_{3} \mathrm{~A}$ menghasilkan kalsium sulpho aluminat dan kalsium aluminat hidrat. Reaksi $\mathrm{C}_{3} \mathrm{~A}$ dengan gypsum $\left(\mathrm{CaSO}_{4} \cdot 2 \mathrm{H}_{2} \mathrm{O}\right)$ menghasilkan kalsium sulfo aluminat $\left(3 \mathrm{CaO} \cdot \mathrm{Al}_{2} \mathrm{O}_{3}\right)$ berbentuk kristal jarum atau ettringate, reaksi tersebut akhirnya menghasilkan kalsium aluminat hidrat berbentuk kristal kubus.

Waktu pengikatan adukan mortar yang lunak menjadi motar yang keras, digolongkan menjadi dua bagian yaitu ikat awal (initial time) yaitu waktu dari pencampuran semen dan air sampai saat sifat plastis akan hilang, dan waktu ikatan akhir(final setting time) yaitu lama pasta menjadi massa yang kera (Tjokrodimulyo, K., 1996).

72 |Media Teknik Sipil, Volume 10, Nomor 1, Februari 2012: 70 - 79
Semen atau portland cement (PC) untuk penggunaan umum yang tidak memerluka persyaratan khusus, dan Portland Pozzolan Cement (PPC) berfungsi untuk menghasilkan panas hidrasi lebih sedikit dari pada PC, dan tahan terhadap kotoran Semen PPC acapkali dipakai untuk bangunan pengairan, dan beton massa (Tjokrodimulyo, 1996) Collepardi, M. et. al. (1994) menyebutkan bahwa penggunaan pozzolan dalam semen mengurangi kekuatannya karena butiran pozzolan menaikkan faktor air semen. Pemakaian pozzolan dengan konsentrasi tinggi dalam campuran beton dan superplastisizer mampu meningkatkan kualitasnya, setting time lebih pendek; Sebelum usia beton 28 hari, kuat lentur lebih tinggi, kuat tarik tinggi, modulus elastisitas rendah, retak shrinkage lebih kecil, dibanding dengan beton dengan silica fume (Zhang, M.H. dan Malhotra, V.M., 1995)

\section{Agregat}

Agregat digolongkan menjadi : batu besar yan berdiameter lebih dari $40 \mathrm{~mm}$, kerikil yang bergari tengah butiran antara $5 \mathrm{~mm}$ sampai $40 \mathrm{~mm}$, dan pasi untuk diameter antara $0.15 \mathrm{~mm}$ dan $5 \mathrm{~mm}$. Agregat yang baik memiliki bentuk bulat atau mendekati kubus, kimia stabil, dan dalam hal-hal tertentu harus tahan aus dan tahan cuaca (Murdock,L.J, 1980). Agregat berasal dari sumber daya alam yang telah mengalam pengecilan ukuran secara alamiah (misalnya kerikil), atau dengan cara memecah batu alam, atau menggal tanah, atau menambang di dasar sungai, atau dari tep laut. Pasir galian, diperoleh langsung dari permukaan tanah atau dengan cara menggali terlebih dahulu. Pasi galian biasanya tajam, bersudut, berpori dan bebas dari kandungan garam, tetapi biasanya harus dibersihkan dari kotoran tanah dengan cara dicuci. Pasir sungai yang berbutir lebih kecil dan berbentuk bulat, akibat gesekan. Pasir pantai berasal dari gerusan atau gesekan batuan di laut. Butiran lebih halus daripada pasir sungai, bentuk bulat karena gesekan, mengandung garam. Garam mengikat air dari udara sehingga butiran pasir agak basah, dan mengembang bila sudah menjad mortar bangunan (Tjokrodimuljo, K, 1996).

Kelayakan agregat endapan atau deposit berhubungan dengan sejarah geologi dari daerah penambangan agregat. Proses geologis berpengaruh pada pembentukan lokasi deposit, bentuk, ukuran, jenis kondisi batuan, gradasi butiran, kebulatan, dan deraja informitasnya. Faktor tersebut berpengaruh pada karakteristik butiran seperti kekuatan hancur butiran atau ketahanan terhadap gesekan atau benturan, kekuatan ikatan antara butiran dengan perekat pasta semen, porositas, dan nilai penyerapan air. Nilai porositas serta penyerapan air terbentuk, karena pengaruh ketahanan butiran agregat terhadap proses pembekuan material pembentuknya saat musim dingin, atau panas, dan agresilarutankimia, serta ketahanan terhadap penyusutan (Murdock L.J., 1980)

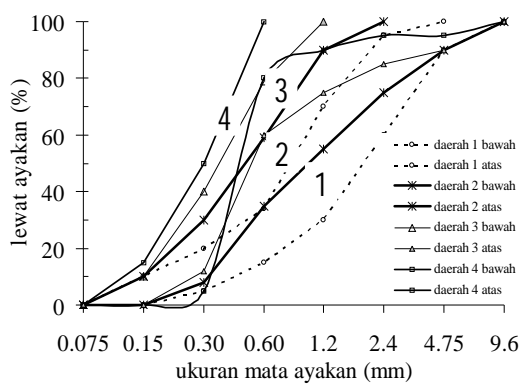

Gambar 2. Pemetaan daerah gradasi pasir

Agregat halus adalah agregat lolos saringan diameter $0,15 \mathrm{~mm}-4,80 \mathrm{~mm}$. British Standard (BS 1881) menyebutkan bahwa distribusi butiran agregat halus dibagi menjadi 4 daerah gradasi seperti dalam gambar di bawah, dari kiri daerah berbutir sangat kecil atau halus, daerah 3 untuk butiran agak halus, daerah 2 butiran sedang, dan paling kanan daerah 4 yaitu pasir kasar. Jika ukuran sama atau seragam, maka volume pori akan besar. Sebaliknya bila ukuran bervariasi menghasilkan volume pori yang lebih kecil. Butiran yang kecil mengisi pori diantara butiran yang lebih besar, sehingga pori menjadi sedikit, dengan kata lain kemampatan massa tinogi. Pasir sebagai bahan penoisi dalam adukan berfungsi untuk mengurangi penyusutan, butiran yang cukup keras dan gradasi yang bervariasi, menghasilkan spesi yang tahan pengaruh cuaca serta than juga pengaruh lain (Supribadi, 1986).

PBI 1971 (Peraturan Beton Bertulang Indonesia 1971) dan PUBI 1982 (Peraturan Bahan Bangunan Indonesia 1982) pasal 3.3 mendefinisikan bahwa pasir berasal dari batuan. Persyaratan pasir sesuai standar tersebut yakni berbutir tajam dan memiliki kekerasan 
yang baik, tidak boleh mengandung lumpur lebih dari $50 \%$ yang ditentukan terhadap berat keringnya, apabila kadar lumpur melampaui $5 \%$ maka harus dicuci, tidak boleh mengandung bahan-bahan organis, terdiri dari butiran-butiran beraneka ragam besarnya pasir laut tidak boleh dipakai sebagai agregat halu kecuali dengan petunjuk dari lembaga pemeriksaa bahan-bahan yang diakui (PBI 1971).

\section{METODELOGI PENELITIAN}

Pasir pantai sebagai bahan penggan (replacement) sebagian pasir sungai sampai denga (replacement) sebagian pasir sungai sampai denga
semuanya dalam spesi. Pasir pantai diambil dari semuanya dalam spesi. Pasir pantai diambil dar pantai Sendangbiru di wilayah Kabupaten Malang sis
selatan Propinsi Jawa Timur. Titik pengambilan selatan Propinsi Jawa Timur. Titik pengambila Selanjutnya dimasukkan ke dalam kantong plastik.

Pemeriksaan karakteristik pasir dilakukan tanpa mencuci pasir. Demikian juga halnya untuk campura mortar segar. Harapan penulis perilaku pemakaia pasir di masyarakat tepi pantai yaitu pasir didiamk dapat digambarkan, walaupun tidak sempurna. Pemeriksaan yang dilakukan seperti :1)analisis gradasi butiran dengan saringan yang tersusun pas mesin penggetar 2)berat isi pasir terdiri atas berat isi lepas yaitu perbandingan berat pasir dalam tempa dengan volumenya, berat isi padat dengan pemadat tusukan, berat isi padat dengan pemadatan getaran. berat jenis, 3)berat jenis, 4)penyerapan air. Nilai yan tertera diperoleh dari rata-rata 3 kali pengujian.

Komposisi campuran mortar dalam perbandingan berat 1 semen : 3 pasir, dengan faktor air semen 0,5 . Jenis semen yang dipakai yaitu jenis PC dan PPC selanjutnya persentase pasir pantai yang

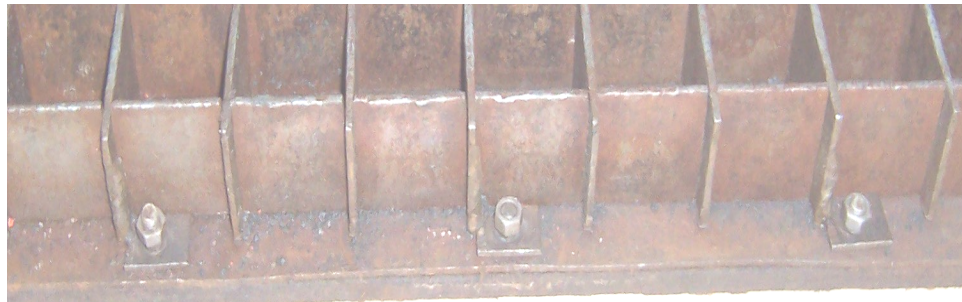

Gambar 3. Cetakan kubus $5 \times 5 \times 5 \mathrm{~cm}$

74 |Media Teknik Sipil, Volume 10, Nomor 1, Februari 2012: 70 - 79
Pemeriksaan kualitas jenis mortar dilakukan kaca yang dinyatakan dalam putaran/menit drum pada dengan memberikan beban merata di atas kubus, nilai mesin Los Angelos (Nurwidayati, R. dalam Besar beban saat kubus mulai retak dibagi dengan luasan M.S., 2007).

tampangkubasadahnila kuttekanmotar(ASTM Standart C 39-93a) Nilai rata-rata kuat tekan morta diperoleh dengan menjumlahkan seluruh nilai hasil uji diperoleh dengan menjumlahkan seluruh nilai hasil uji
tekan dan dibagi dengan jumlah spesimen. Selanjutnya nilai rata-rata dituang dalam gambar kurva

\section{HASIL DAN PEMBAHASAN}

Hasil pemeriksaan semen merek Semen Gresik yang dibeli di toko bahan bangunan di Landungsai lang menyatakn kehalusan butiran semen $\cdot 90,8 \%$, uji konsistensi semen kehalusan butiran semen : $90,8 \%$, uji konsistensi semen
$: 24,5 \%$, dan nilai pengikatan semen awal : 135 meni serta akhir 170 menit. Nilai-nilai tersebut sesuai dengan standar SNI 15-0302-94, dan ASTM C 595-00a. Semen dalam kondisi baik dan dapat digunakan dalam campuran mortar.

Hasil pengujian pada semen jenis PPC menunjukkan berat jenis semen merek Semen Gresik jenis PPC sebesar 3.153 , kehalusan semen yaitu 92,74 $\%$, konsistensi semen sebesar $26 \%$, dan pengikatan semen awal 150 menit serta akhir 210 menit. Waktu menunjukkan bahwa semen yang digunakan dalan kondisi baik dan layak digunakan dalam campura mortar

Pasir pantai

Pengamatan di lapangan menunjukkan jumlah pasir cukup banyak. Luas pantai Sendangbiru, kirakira sejauh $170 \mathrm{~m}$ dari garis laut saat surut ke arah daratan, sepanjang pantai $850 \mathrm{~m}$, dan denga penggalian dalaman $1,72 \mathrm{~m}$ terkandung butiran pasir.

Pengamatan dengan penglihatan mata menunjukkan bahwa besar butiran pp lebih kecil daripada ps. Hasil pengamatan yang mungkin kurang valid dengan genggaman jari-jari tangan, ternyata pasir sungai memiliki nilai ketajaman atau kekasara permukaan butiran yang lebih besar daripada pasi pantai. Mestinya kekasaran butiran agregat halus dapat diukur, sebagaimana kekasaran butiran kelereng

Hasil pemeriksaan berat jenis kering pp Sendangbiru menunjukkan nilai $2,63 \mathrm{~kg} / \mathrm{m}^{3} \mathrm{saat}$ kondis saturated surface dry (ssd), dan Nilai berat jenis pada kondisi kering sebesar $2,55 \mathrm{~kg} / \mathrm{m} 3$. Pengujian berat jenis kering ps Brantas menunjukkan hasil sebesar 2,57 $\mathrm{kg} / \mathrm{m}^{3}$, dan $2,65 \mathrm{~kg} / \mathrm{m}^{3}$ untuk nilai berat jenis kondisi ssd. Kedua nilai ini hampir tidak berbeda, keduanya sesuai dengan persyaratan berat jenis agregat normal yaitu antara 2,5-2,7 (Tjokrodimulyo, 1996).

Nilai penyerapan pp sebesar $2,16 \%$, sedangkan nilai penyerapan ps adalah $2,89 \%$. Nilai penyerapan ps lebih besar 0,63 daripada pp, beda ini disebabkan oleh kondisi geologis dan proses terjadinya butiran pasir (Murdock L.J., 1980)

Berat isi rata-rata pasir pantai Sendangbiru adalah $1,4695 \mathrm{ton} / \mathrm{m}^{3}$, beberapa hasil lain yaitu nilai berat isi lepas : $1,4101 \mathrm{ton} / \mathrm{m}^{3}$, berat isi padat dengan penusukan : $1,4713 \mathrm{ton} / \mathrm{m}^{3}$, dan berat isi padat dengan dilakukan penggoyangan : $1,5271 \mathrm{ton} / \mathrm{m}^{3}$. Berat is rata-rata pasir sungai Brantas adalah 1,7739 ton $/ \mathrm{m}^{3}$ lemikian juga nilai-nilai lainnya, seperti berat isi lepas sebesar 1,7229 ton $/ \mathrm{m}^{3}$, berat isi padat dengan penusukan sebesar 1,7912 ton/ $\mathrm{m}^{3}$, dan dengan penggoyangan nilai berat isi yaitu $1,8077 \mathrm{ton} / \mathrm{m} 3$. Nilai berat isi ps Brantas lebih besar daripada pp Sendangbiru. Nilai tersebut mengambarkan bahwa kepadatan dalam tabung uji yang berisi ps Brantas lebih tinggi daripada pp Sendangbiru. Kepadatan lebih tinggi dapat disebabkan oleh gradasi butir ps yang beranekaragam, sedangkan gradasi pp seragam, terbukti hasil gradasi pp Sendangbiru yang tertahan pada ayakan nomer 50 Brantas.

Nilai kandungan lumpur pasir pantai Sendangbiru sebesar $1,452 \%$, dan ps Brantas sebesar $1.424 \%$, nilai tersebut telah memenuhi yang disyaratkan dalam PBBI (Pasal 3.3 ayat 3 ), yaitu kandungan lumpur pada agregat halus harus lebih kecil dari $5 \%$, sehingoa pasi pantai tidak perlu dicuci. Jika nilai keduanya dibandingkan, maka nilai pp Sendangbiru lebih kecil daripada ps Brantas. Jadi butiran pp lebih bersih disbanding butiran ps Brantas, tampaknya siraman air laut secara terus menerus mampu membersihkan butiran dari debu serta menepikannya di pantai.

AlikAnsyori Alamsyah, Penggunaan Pertamax Sebagai Modifier Pada Lasbutag Campuran Dingin $\mid \mathbf{7 5}$ Untuk Perkerasan Jalan 
Hasil pemeriksaan gradasi pasir menunjukkan tertahan pada ayakan nomer $50(0,3 \mathrm{~mm})$ berjumlah bahwa butiran berdiamater kecil diantara $0,075 \mathrm{~mm}-\quad 61,95 \%$. Nilai tersebut adalah nilai terbesar daripada $1,2 \mathrm{~mm}$, atau berbutir lembut. Persentase butiran yang persentase butiran yang tertahan ayakan nomor lain.

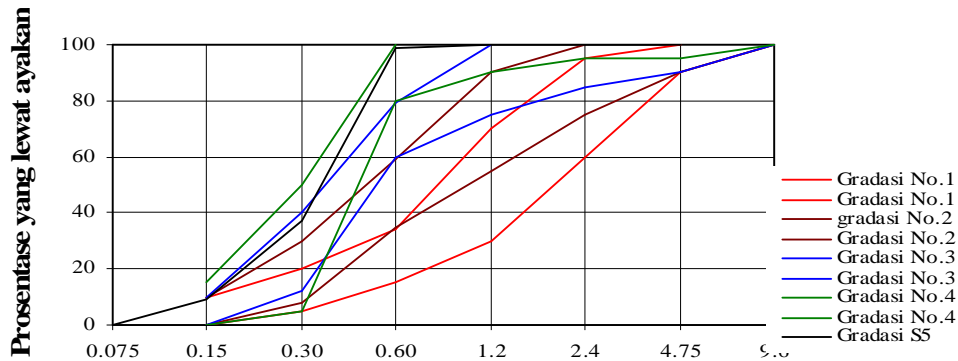

ukuran mata ayakan (mm)

Gambar 4. Hasil Analisis Gradasi Pasir Pantai Sendang Bir

Nilai konsistensi mortar dengan perbandingan banyak, dan memang nilai yang menggambarkan 1pc : 3 pasir, ditunjukkan pada Tabel 2. berikut ini. kelecakan masing-masing campuran tersebut Nilai yang tertera tampak tidak banyak berbeda diharapkan sama.

\section{Tabel 3. Nilai konsistensi mortar dengan 1pc:3pasir pantai yang disbustitusi oleh pasir sungai} Brantas

\begin{tabular}{|c|c|c|c|c|}
\hline \multicolumn{2}{|c|}{ pasir (\%) } & & \multirow[b]{2}{*}{$=\frac{\bar{D}}{D} \times 100 \%$} \\
\hline \multirow{2}{*}{\multicolumn{2}{|c|}{ pantaisungai }} & Jenis & & \\
\hline & & & $(\bar{D}$ & $(\mathrm{mm})$ \\
\hline \multirow{2}{*}{100} & \multirow{2}{*}{0} & PC & 113.5 & 112.9 \\
\hline & & PPC & 113.6 & 113.0 \\
\hline \multirow{2}{*}{80} & \multirow{2}{*}{20} & PC & 114.6 & 114.0 \\
\hline & & PPC & 114.8 & 114.2 \\
\hline \multirow{2}{*}{60} & \multirow{2}{*}{40} & PC & 114.3 & 113.7 \\
\hline & & PPC & 114.5 & 113.9 \\
\hline \multirow{2}{*}{40} & \multirow{2}{*}{60} & PC & 114 & 113.4 \\
\hline & & PPC & 114.2 & 113.6 \\
\hline \multirow{2}{*}{20} & \multirow{2}{*}{80} & PC & 113.7 & 113.1 \\
\hline & & PPC & 113.9 & 113.3 \\
\hline \multirow{2}{*}{0} & 100 & PC & 114.7 & 114.1 \\
\hline & & PPC & 114.9 & 114.3 \\
\hline
\end{tabular}

Kuat tekan

Kuat tekan mortar semen PC dan PPC umur 14 hari

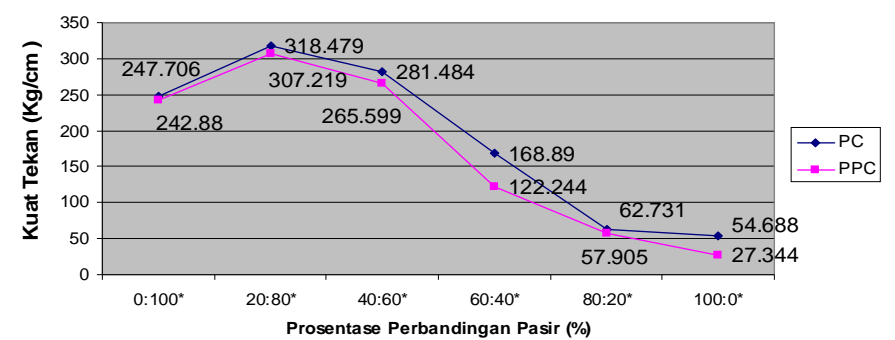

Gambar 5. Nilai kuat tekan mortar pada umur 14 hari.

76 |Media Teknik Sipil, Volume 10, Nomor 1, Februari 2012: 70 - 79

Gambar di atas menunjukkan nilai kuat tekan menjadi, 68\%, 25\%, dan 22\%, pada campuran pp mortar pada umur 14 hari. Nilai kualitas mortar dengan Sendangbiru: ps Brantas 60\%:40\%, 80\%:20\%, dan semen jenis pc lebih tinggi daripada mortar bersemen jenis ppc. Pada campuran $100 \%$ pp Sendangbiru nilai tekan mortar bersemen pc hampir sama dengan dengan ps Brantas, hal ini menunjukkan bahwa kinerja semen pc yang tidak memiliki unsur pozzolan lebih baik daripada semen ppc yang mengandung pozzolan. Kinerja mortar berpasir sungai sampai dengan $60 \%$ dan $40 \%$ lainnya disustitusi pasir pantai masih menunjukkan kualitas yang lebih baik daripada kontrol.

Kinerja tekan mortar terbaik ditunjukkan oleh campuran $20 \%$ pp Sendangbiru dan $80 \%$ ps Brantas, yaitu $318,479 \mathrm{Kg} / \mathrm{cm}^{2}$, atau berkisar $28.5 \%$ lebih besar daripada mortar kontrol (1semen pc: 3ps Brantas) sebesar $247,706 \mathrm{Kg} / \mathrm{cm}^{2}$. Demikian pula pada compuran $40 \%$ pp Sendangbiru dan $60 \%$ ps Brantas, . $281,5 \mathrm{Kg} \mathrm{cm}^{2}$, a berk (ait $281,5 \mathrm{Kg}$, daripada mortar kontrol. Selanjutnya kuat tekanmortar
bersemen pc bersubstitusi pasir pantai menurun

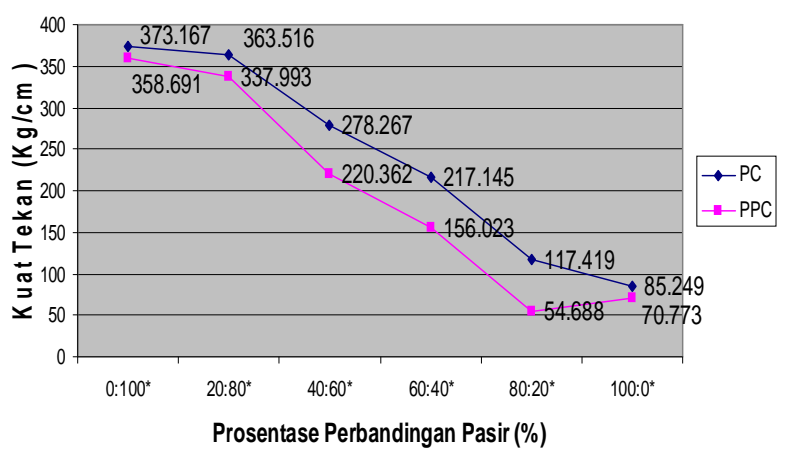

Gambar 6. Nilai kuat tekan mortar pada umur 28 hari
Nilai kuat tekan rata-rata mortar dengan semen jenis pc lebih tinggi daripada mortar bersemen jenis ppc, pada umur 28 hari. Sebagai kontrol adalah nilai tekan mortar pada campuran $100 \%$ ps Brantas bersemen pc sebesar $373,2 \mathrm{~kg} / \mathrm{cm}^{2}$. Kuat tekan bers. campuran pc sebesar $373,2 \mathrm{~kg} / \mathrm{cm}$. Kuat tekan rendah daripada nila kontrol. Nilai kuat tekan mortar substitusi pasir panta $20 \%, 40 \%, 60 \%, 80 \%$, dan $100 \%$ masing-masing turu menjadi $97,4 \%, 74,5 \%, 58,2 \%, 31,5 \%$, dan $22,8 \%$ da kontrol
Salah satu penyebab adalah kalsium silikat yang bereaksi dengan air menghasilkan kalsium silikat hidrat (calsium silicate hydrate atau C-S-H) dan kalsium hidroksida belum optimal, sehingga sifat CSH keras belum tercapai. Kandungan unsur kalsium silikat dalam semen pc berbeda dengan jenis ppc, sehingga jumlah kalsium silikat hidrat yang menyebabkan kerasnya mortar berbeda. Kekerasan yang berbada akan menunjukkan kuat tekan yang berbeda pula. Penyebab lain adalah faktor gradasi yang terbentuk dalam masing-masing komposisi. Pada persentase 20\% pp dan $80 \%$ ps membentuk formasi yang lebih pada dibanding dengan formasi lainnya, sehingga memunculkan kualitas tekan yang tinggi.

Kuat Tekan Mortar PC dan PPC umur 28 hari

Penurunan disebabkan karena massa specimen yang kurang pada, sebagaimana dinyatakan oleh Neville (1981), serta Tjokrodimuljo (1996) bahwa faktor kepadatan spesimen yang dibentuk oleh susunan gradasi agregat sangat berpengaruh pada kualitas mortar, hampir 70\% kekuatan benda uji didukung oleh kualitas agregat. Kepadatan kubus yang tersusun agregat pasir sungai lebih kompak karena gradasi pasir sungai kompak, butiran saling mengisi ruang antara butiran. Sedangkan pada kubus bergregat pasir panta yang bergradasi seragam memiliki rongga yang lebih banyak daripada kubus berpasir sungai.

AlikAnsyori Alamsyah, Penggunaan Pertamax Sebagai Modifier Pada Lasbutag Campuran Dingin $\mid 77$ Untuk Perkerasan Jalan 
Kuat lentur mortar bersemen ppc, komposisi Ipc:3pasir, dengan pasir pantai yang mensubstitusi pasir sungai lebih rendah daripada nilai kontrol. Nilai kuat tekan mortar bersemen ppc berpasir sungai Brantas $363,5 \mathrm{~kg} / \mathrm{cm}^{2}$. Selan kuat tekan mortar berpasir sungai yang disubstitusi dengan pasir pantai sebanyak $20 \%, 40 \%, 60 \%, 80 \%$, dan $100 \%$, masing-masing turun menjadi $94,2 \%, 61,5 \%, 43,5 \%, 15,5 \%$, dan $19,7 \%$ dari nilai kuat tekan mortar beremen ppc, $363,5 \mathrm{~kg} / \mathrm{cm}^{2}$

Kinerja semen pc yang tidak memiliki unsur pozzolan lebih baik daripada semen ppc yang mengandung pozzolan. Penyebab penurunan tersebut sama dengan kasus pada umur 14 hari yaitu kalsium silikat yang bereaksi dengan air menghasilkan kalsium slikathidad (calsium silicate hydrate atau C-S-H) dan kalsium hidroksida tidak optimal. Kandungan $\mathrm{C}_{3} \mathrm{~S}$ dan $C_{2} S$ pada semen jenis pc lebih tinggi daripada jenis ppc, sehingga jumlah kalsium silikat hidrat yang menyebabkan kerasnya mortar berbeda. Kekerasan yang berbeda akan menunjukkan kuat tekan yang berbeda pula. Penyebab lain adalah faktor gradasi yang terbentuk dalam masing-masing komposisi. Pada persentase $20 \%$ pp dan $80 \%$ ps dan seterusnya membentuk formasi yang kurang padat dibanding dengan formasi mortar kontrol, sehingga memunculkan kualitas tekan yang kurang daripada kuat tekan kontrol.

\section{KESIMPULAN DAN SARAN}

\section{Kesimpulan}

1. Kuat tekan rata-rata mortar dengan 1 semen $\mathrm{PC}$ : 3 pasir sungai lebih tinggi daripada mortar dengan 1semen PPC : 3 pasir sungai, demikian juga pada mortar berpasir pantai.

2. Pemakaian pasir pantai untuk bahan bangunan seperti mortar dapat dilakukan dengan komposisi 1semen PC : 3 pasir yang tersusun atas 20\% pasir pantai dan $80 \%$ pasir sungai, Kuat tekan rata-rata mortar tersebut umur 14 hari lebih tinggi 1,7\% daripada mortar dengan pasir sungai. Kuat tekan tersebut menurun menjadi $82 \%$ pada umur 28 hari.

3. Berat jenis pasir pantai lebih tinggi daripada pasir sungai, tetapi berdiamater lebih kecil daripada pasir sungai.
4. Kandungan kotoran pada butiran pasir pantai di bawah 5\% standar PUBI, namun demikia pemakaiannya sebagai bahan bangunan perlu dikaji lebih lanjut.

5. Penyerapan air, berat jenis, kadar lumpur, ukuran diameter, kekasaran permukaan, kadar air semen, jenis semen, dan berpengaruh pada kuat tekan mortar, selain itu diperhatikan juga kandungan unsur kimia dalam butiran pasir.

\section{SARAN}

. Nilai asam atau basa pada pasta semen jeni portland maupun pozzolan portland sebaikny diukur.

2. Derajad garam pada pasir pantai sebaiknya diukur, sehingga mendapatkan nilai yang sama pada setiap campuran.

3. Nilai asam atau basa pada campuran mortar sebaiknya diukur.

4. Perlu diperhatikan laju angin, yang memungkinkan membawa debu atau kotoran.

5. Lokasi pengambilan sebaiknya dekat air laut, agar mendapatkan butiran pasir yang relatif tidak berdebu.

6. Penelitian lebih lanjut diharapkan untuk menyempurnakan hasil penelitian ini

\section{DAFTAR PUSTAKA}

Amalia Rizki, 2006, Pemanfaatan penggunaan pasir pantai Malang Selatan (Sendangbiru) pada pencampuran mortar, Skripsi tidak dipublikasikan, Jurusan Sipil Fakultas Teknik Universitas Muhammadiyah Malang.

Anonimous, 1982, Persyaratan Umum Bahan Bangunan di Indonesia (PUBBI 1982), Pusa Penelitian dan Pengembangan Pemukiman Badan Penelitian dan Pengembangan PU, Bandung

Anonimous, ASTM Designation C157 - 75 . Standard Test. Method for Length Change of Hardenend Cement. Mortar and Concrete, ASTM Standard, part 14 : 1976, 111
Besari, Muhammad Sahari, 2007, Review Some Physical and Mechanical Parameters of Concrete, Proceeding of International Conference on Material Development in The Construction Industri on November 21 , 2007, Four Season Hotel Jakarta

Collepardi, M., S. Monosi, P. Piccioli, 1994, The Influence of Pozzolanic Materials on The Mechanical Stability of Aluminous Cement, Cement and Concrete Research, Vol. 25. NO. 5, pp. 961-968.

Dwi, M.R, 2004, Pemanfaatan Pasir Pantai Utara Jawa Timur Sebagai Spesi, Skrips Tidak Dipublikasikan, Surabaya : Jurusan Sipil FT UNESA

Husaini M. dan Dwi, M.R, 2004, Profil Pasi Pantai Lamongan dan Gresik, Laporan Penelitian, Tidak Dipblikasikan Surabaya : Lembaga Penelitian UNESA

Murdock L.J dan Brook K.M., 1980, alih bahas Hindarko Stepanus, Bahan dan Praktek Beton, Jakarta : Erlangga

Neville, A.M, 1981, Properties of Concrete, Longman Scientific and Technical, New York

Nurwidayati, R., 1998, Pengaruh Kekasaran Permukaan Agregat Kasar pada Beton dengan Sistem Grouting, Tesis Magister Tidak Dipublikasikan, Program Pascasarjana, Institu Teknologi Bandung.

Suhendro, Bambang, 2003, Pengembangan Teknik Sipil-Struktur Masa Depan dan Kaitannya dengan Bidang-bidang Lain, Pidato Pengukuhan Jabatan Guru Besar pada Fakultas Pengukuhan Jabatan Guru Besar pada Fakultas
Teknik Universitas Gadjah Mada, Yogyakarta

Supribadi, I Ketut, 1996, Ilmu Bangunan Gedung, Bandung : ARMICO

Suprapto, 2002, Kuat tekan mortar beragregat pecahan kerang, Laporan Penelitian tidak dipublikasikan, Surabaya : Lembaga Penelitian UNESA
Tim Penyusun Departemen Pekerjaan Umum, 1990, Tata Cara Pembuatan Rencana Campuran Spesi Normal SKSNI 1 - 15 - 1990 - 03, Bandung : Yayasan LPMB

Tjokrodimuljo, Kardiono. (1996), Teknologi Beton, Yogyakarta : Nafiri

Trimulyono, Ir, MT. (2004), Teknologi Beton, Yogyakarta: Andy

Zhang, M.H. dan V.M. Malhotra, 1995 Characteristics of a Thermally Activated Alumino-Sili Alumino-Silicate Pozzolanic Material and it Use in Concerete, Cement and Concrete
Research, Vol. 25. No. 8. pp. 1713-1725.

Wahyudi, Yusuf, 2000, Ketahanan Mortar dan Beton dengan Abu Sekam dalam Serangan Chlorida, Tesis Magister, Tidak Dipublikasikan, Universitas Gadjah Mada

Wahyudi, Yusuf, 2006, Pasir Pantai sebagai bahan Pengisi Spesi? Prosiding Seminar Nasional Teknik Sipil di Universitas Muhammadiyah Malang 9 Desember 2006. Malang : UMM press

Wuryati, S. dan Candra, R., 2001, Beton dan Karakteristiknya, Bandung

http://www.menlh.go.id/i/art/pdf_1038897326.pdf Wijanto Sigit Eddie, 2006, Limbah B3 dan Kesehatan 